\title{
Species composition and habitat association of anurans within water systems of Andanan Watershed, Agusan del Sur, Caraga Region, Philippines
}

\author{
Chennie L. Solania*, Eve V. Fernandez-Gamalinda \\ Department of Biology, College of Arts and Sciences, Caraga State University, Ampayon, Butuan City 8600, Agusan del Norte, \\ Philippines
}

${ }^{\star}$ Corresponding author, E-mail: 888cheny@gmail.com

\begin{abstract}
An intensive anuran survey was conducted using cruising and mark-release-recapture methods for a total of 168 man-hours on April 28 to 30,2017 at Barangay Calaitan, Andanan Watershed, Bayugan, Agusan del Sur. The study aimed to record and statistically define anuran species populations in three types of water systems (streams and creeks, the river of Calaitan, and Lake Danao) with notes on habitat association; and to provide additional baseline data to the existing records of Mindanao amphibian fauna. A total of 141 individuals of anurans belonging to eleven species and seven families were recorded, of which 73\% were Philippine endemics, and 36\% were Mindanao faunal endemics. Only Megophrys stejnegeri was regarded as vulnerable and Limnonectes magnus as near threatened by IUCN 2016. The diversity of anurans was highest in Lake Danao $\left(H^{\prime}=1.69, S=7, n=54\right)$ followed by anuran diversity in the Calaitan river $\left(H^{\prime}=1.40, S\right.$ $=7, n=42)$, and in the streams and creeks $\left(H^{\prime}=1.30, S=6, n=43\right)$, with no significant difference $(p=0.9167)$. However, anuran species composition differd between sites $(p=0.038)$. Microhabitat overlap was observed in anuran preferences since many of the encountered species utilized both aquatic and terrestrial microhabitats. An ordination biplot (canonical correspondence analysis) revealed two habitat types, wherein M. stejnegeri and Platymantis dorsalis were associated with humidity, canopy cover, moss percentage, rock percentage and distance to disturbance. Philippine endemic species were closely associated with forest habitats. However, the presence of forest clearings for cultivation was an indicator of forest degradation. The high degree of endemism and presence of threatened taxa indicated a need for conservation intervention since anthropogenic activities were evident even in highlands of the protected area.
\end{abstract}

Key words: anurans, distribution, keystone species, Mindanao-endemic, forest-associated.

Abbreviations: FL, forelimb length; HL, head length; HW, head width; LL, leg length; masl, meters above sea level; SVL, snout to vent length; TW, total weight.

\section{Introduction}

The Philippines sits at the undisputed top regarding concentration of endemic vertebrate species (Brown, Diemsos 2009). Extensive research conducted in the Philippines placed the country as a significant center of amphibian diversity and endemism (Diesmos, Brown 2011). However, in greater Mindanao survey efforts are incomplete, and much of the remaining forest area is deficient for herpetofaunal data. The greater Mindanao is one of the nine recognized Pleistocene Aggregate Island Complexes, as hypothesized by Heaney (1985), which correspond to centers of herpetofaunal diversity and endemism.

There are 112 amphibians recorded in the Philippines (Diesmos et al. 2015), of which three species are caecilians, and 109 species are anurans, and more than $80 \%$ are endemic to the Philippines (Diesmos, Brown 2011). Amphibians occupy different habitats (aquatic and terrestrial) during their lifecycle, feed on various food sources (Whiles et al.
2006), and are essential prey to higher forms of organisms (Petranka, Murray 2001). They are regarded as good indicators of environmental stress (Blaustein, Wake 1995) and are keystone species. Despite their significance, the amphibian species populations have experienced global declines (Prieto, Juricic 2005). Amphibians are susceptible even to minor forest degradation (Ernst et al. 2006). Forest degradation and fragmentation can affect amphibian site fidelity and can limit dispersal ability (Marsh, Pearmann 1997). This threat highlights the importance of maintaining intact forest blocks (Ernst et al. 2006).

The Andanan River Watershed Forest Reserve supports potable drinking water and irrigation for Bayugan, Sibagat, and other areas of Agusan del Sur. The watershed is protected under Proclamation No. 734, S. 1991 (PENRO Agusan del Sur 2016). However, few studies have been performed within its range (only mere counts and identifications) and no thorough scientific studies have been conducted primarily on keystone amphibians, and more specifically anurans. Thus, anuran assessment and habitat association 
within the water systems of Andanan Watershed, Agusan del Sur was undertaken to compare biodiversity indices of anurans in three water systems, provide species accounts for each anuran species encountered, and assess the habitat association of anurans in the area.

\section{Materials and methods}

\section{The study area}

The Andanan Watershed Forest Reserve extends through the areas of Bayugan City and Sibagat and has a total area of 15097 ha. Cultivated and secondary growth forest characterizes the watershed. The sampling was conducted in the forest of Barangay Calaitan, Bayugan City, Agusan del Sur. The water systems within the watershed were categorized into three types: Calaitan river, the streams and creeks, and Lake Danao (Fig. 1).

Site 1: Calaitan river $\left(8^{\circ} 45^{\prime} 59.6232^{\prime \prime} \mathrm{N}, 125^{\circ} 46^{\prime} 46.6392^{\prime \prime}\right.$ E). The Calaitan river is part of the Andanan Watershed Forest River as this river drains towards the watershed. The elevation ranges from 109 to 140 meters above sea level (masl). The riparian zone of the river is characterized by a dense combination of shrubs, ferns, and grasses. Boulders and rocks are abundant along sides, and some obstruct the water flow. The width of the river bed varies between 5 to $10 \mathrm{~m}$. Since streams and creeks located at higher elevation drain towards the river, the river flows sometimes fluctuate from a slow to fast water velocity, especially during rain periods when all the water from the forest empties into the river.

Site 2: streams and creeks $\left(8^{\circ} 45^{\prime} 54.3528^{\prime \prime} \mathrm{N}\right.$, $\left.125^{\circ} 46^{\prime} 48.4176^{\prime \prime} \mathrm{E}\right)$. The streams and creeks of the area are located within 116 to 183 masl. Cultivated areas adjacent to the water systems include plantations of falcata
(Paraserianthes falcataria), coconut (Cocos nucifera), banana (Musa spp.), cassava (Manihot esculenta), and eggplant (Solanum melongena). Streams and creeks are narrower and shallower compared than the river. Water velocity is faster with a less turbid stream bed. Several water pipes were ends have been placed in the streams and creeks, indicating that they are sources of water for the local communities.

Site 3: Lake Danao ( $8^{\circ} 47^{\prime} 0.5352^{\prime \prime}$ N, $125^{\circ} 46^{\prime} 42.798^{\prime \prime}$ E). Lake Danao is surrounded by a cultivated plantation of falcata, banana, and corn (Zea mays) with patches of secondary growth forest. The elevation of the water system ranges from 193 to 290 masl. Grasses and sedges dominate the riparian zone. Water inundation along the immediate riparian zone usually occurs during extended periods of rain. Tilapia is cultured in some parts of the lake as a source of food and income. Locals report that "pagpanulo," a local term for amphibian harvesting for food consumption, occurs frequently.

\section{Anuran survey}

Cruising and mark-release-recapture methods were employed in each sampling site in a standardized strip transect of $10 \times 100 \mathrm{~m}$ (Supsup et al.2016). Six strip transects were placed in each site with a distance of $50 \mathrm{~m}$, and each transect was divided into 10 points for habitat assessment. A total of 18 transects with 198 points were established. Actual field sampling was conducted with diurnal (8:00 to 12:00), and nocturnal (18:00 to 22:00) searches on April 28 to 30,2017 with a total of 168 man-hours (seven field workers $\times 8 \mathrm{~h} /$ day $\times 3$ days). Microhabitat preferences of anurans were noted. The microhabitats were classified into three types: Type I or arboreal if anurans were observed in above ground vegetation; Type II or aquatic, if anurans

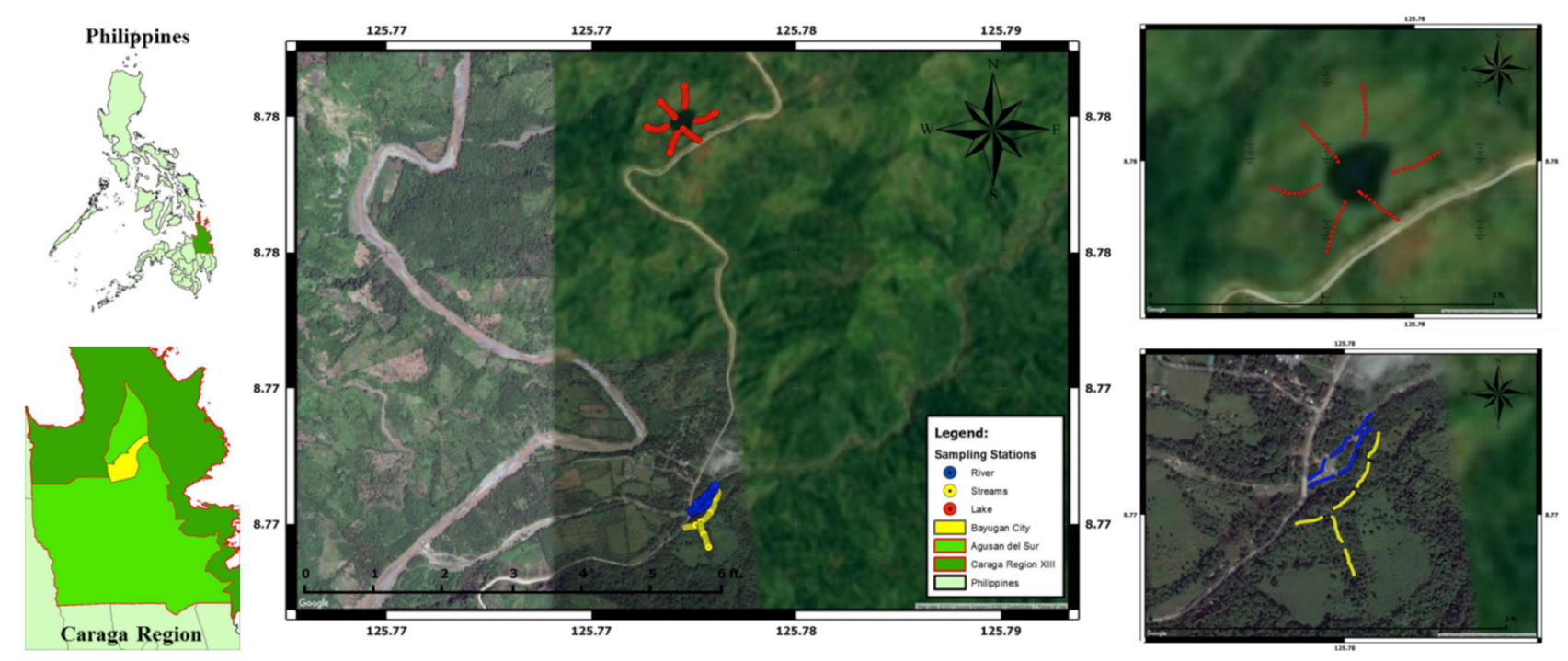

Fig. 1. Map of the sampling stations showing the study sites in Barangay Calaitan, Andanan Watershed Forest Reserve. Inset left: map of the Philippines (upper) and map of Bayugan City (bottom); inset right: lake study sites (upper) and river and streams study sites (bottom). 
were found on rocks in the water system; and Type III or terrestrial, if anurans are seen directly on the ground or among leaf litter (Plaza, Sanguila 2015). Morphometric measurements [snout to vent length (SVL), head width (HW), head length (HL), forelimb length (FL), leg length (LL), and total weight (TW)] were performed, coupled with detailed photo documentation. Statistical analysis was done using the freeware Paleontological Statistics software version 2.17c. A Wildlife Gratuitous Permit was secured before the survey with permit number R13-2017-10.

\section{Results and discussion}

\section{Habitat type composition and characteristics}

Three types of water systems were identified within Barangay Calaitan, Andanan Watershed, Agusan del Sur, which includes the Calaitan River, the streams and creeks, and Lake Danao. Each water system included a transition between cultivated and secondary growth forest (Table 1). The environmental variables of the area had a direct relationship to amphibian abundance and microhabitats. Percent canopy cover was slightly higher in Lake Danao (compared to other areas) but cultivated falcata composed this dense canopy. Mosses and rocks were observed in the area. Ground cover composed of several kinds of grass, sedges, weeds, ferns, and shrubs was 10 to $92 \%$. The thick leaf litter of Lake Danao provided hiding places for several terrestrial and aquatic anurans. Overall distance of recorded individuals to water varied between a zero to at most 500 meters perpendicular to the water. The further records from water were for a forest dwelling anurans. Lake Danao was much more accessible than the other water systems as the terrain was flat, leading to greater disturbance rate in the area. The temperature at night during the intensive sampling varied between 28 and $30{ }^{\circ} \mathrm{C}$ with a relative humidity of 93 to $96 \%$.

Principal component analysis was conducted to examine the interrelationships of the environmental variables recorded at the sampling stations. The Calaitan River (upper right corner) had high percentage of rocks, high temperature, low distance to water system and disturbance. Lake Danao (upper left corner) had high percentage of ground cover and the thickest litterfall, providing many hiding places for anurans and most especially reptiles. The stream area had high moss and canopy cover, typical of a forest habitat; several dipterocarps were observed in the area, but patches of falcata plantation occurred (Fig. 2).

\section{Anuran community, endemicity, and microhabitats}

A total of 141 individuals of anurans belonging to 11 species and seven families were recorded in the study area (Table 2). This study is the first to report species composition of anurans in the Andanan Watershed Forest Reserve. Seventythree percent of the anurans species were endemic to the Philippines, and 36\% were Mindanao faunal endemics (Limnonectes magnus, Megophrys stejnegeri, Kalophrynus pleurostigma, and Pulchrana grandocula). Dicroglossidae was the most species-rich family. There were two invasive and introduced species observed: the commercially edible Hoplobatrachus rugulosus and the failed biological control agent, Rhinella marina (Fig. 3).

Three socio-economically important anurans were documented in the study area: L. magnus (locally known as "bak-bak"), H. rugulosus (locally known as "bullfrog") and Fejervarya vittigera. M. stejnegeri was listed by the IUCN (2016) as a vulnerable species because of the limited area occupied (Mindanao Fauna) and its microhabitat preference (only observed in streams and ground at high elevation). Fejervarya moodiei was listed as Data Deficient because its population status was currently unknown. Most of the species encountered were least concern species (73\%) of the IUCN (2016).

Sanguila et al. 2016 recently summarized the known herpetofauna of Northeastern Mindanao and recorded 40 species of amphibians. Of these records, $27.5 \%$ were noted in Andanan Watershed. It is interesting to note that in our survey one species (F. moodiei) is a new record for Agusan del Sur, since there were no historical records of this species.

Anuran species composition was also surveyed in nearby watersheds. Thirteen species of anurans were

Table 1. Habitat characteristics of selected variables within the water systems of Andanan Watershed, Agusan del Sur, Philippines

\begin{tabular}{lcccc} 
Habitat variables & Range & \multicolumn{3}{c}{ Mean \pm SE } \\
\cline { 2 - 5 } & & Calaitan river & Streams and creeks & Lake Danao \\
Canopy cover (\%) & $5.00-80.00$ & $30.00 \pm 9.22$ & $30.45 \pm 8.16$ & $33.33 \pm 9.89$ \\
\hline Moss (\%) & $0.00-30.00$ & $10.00 \pm 4.28$ & $8.56 \pm 2.74$ & $3.17 \pm 0.91$ \\
Rock (\%) & $5.00-50.00$ & $26.67 \pm 7.49$ & $16.06 \pm 6.64$ & $1.17 \pm 0.83$ \\
Ground cover (\%) & $10.00-92.00$ & $46.67 \pm 12.30$ & $60.68 \pm 14.46$ & $66.67 \pm 9.89$ \\
Leaf litter depth & $1.00-5.00$ & $2.33 \pm 0.67$ & $1.33 \pm 0.13$ & $4.67 \pm 0.21$ \\
Distance to water system $(\mathrm{m})$ & $0.00-500.00$ & $5.83 \pm 0.83$ & $162.80 \pm 96.31$ & $4.83 \pm 0.75$ \\
Distance to disturbance $(\mathrm{m})$ & $2.00-150.00$ & $10.83 \pm 3.00$ & $32.23 \pm 23.69$ & $6.33 \pm 1.20$ \\
Temperature $\left({ }^{\circ} \mathrm{C}\right)$ & $28-30$ & 30 & 28 & 29 \\
Humidity $(\%)$ & $93-96$ & 93 & 96 & 96 \\
Habitat type & & Cultivated habitat and secondary growth forest
\end{tabular}




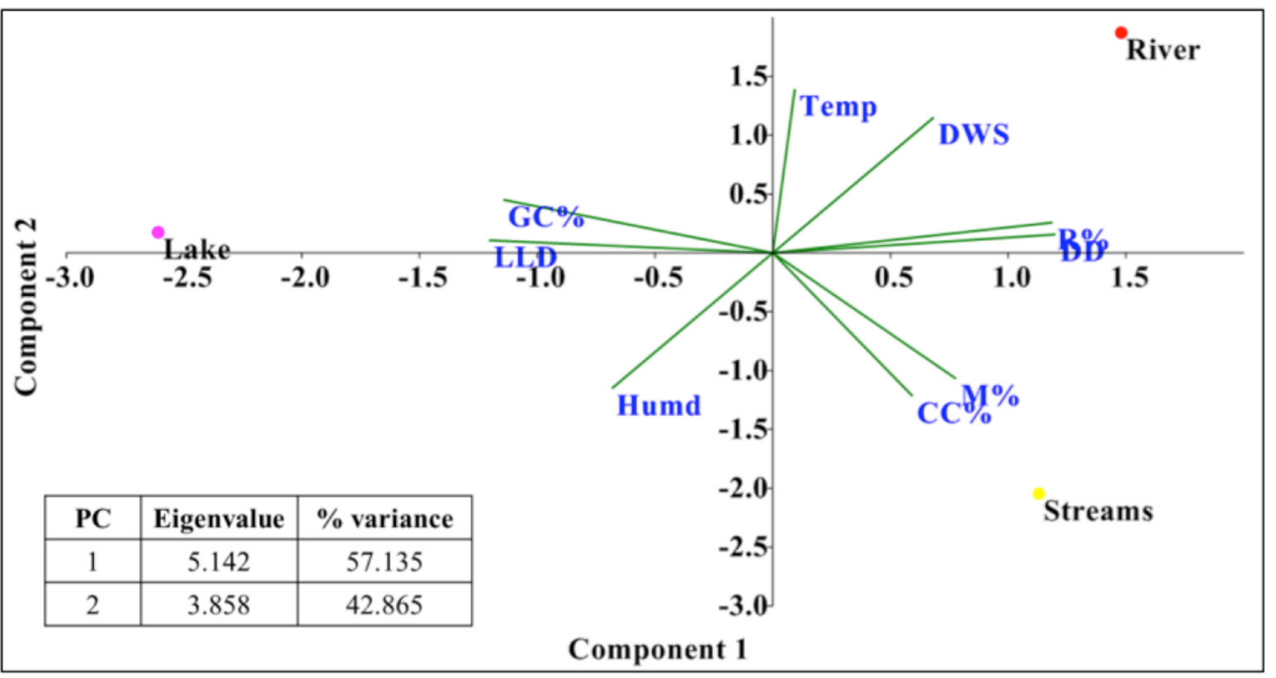

Fig. 2. Principal component analysis (PCA) of the sampling stations in relation to the habitat variables measured within the water systems of Andanan Watershed, Agusan del Sur. GC, ground cover; LLD, leaf litter depth; Humd, humidity; Temp, temperature; DWS distance to water system; R, rock; DD, distance to disturbance; M, moss; CC, canopy cover.

recorded in Bega Watershed, Prosperidad with seven endemic species (54\%) and one Mindanao island endemic, M. stejnegeri (Calo, Nuñeza 2015). Survey of Mt. Magdiwata Watershed Forest Reserve, yielded 12 anuran species with relatively moderate endemism (50\%) (Jacosalem 2005). The recorded endemicity in the area was high compared to nearby watersheds.

Several species utilized two of the three types of microhabitats considered in the study (Table 2). Of the eleven species recorded only four were encountered in all sites: R. marina, L. magnus, P. grandocula and Polypedates leucomystax. The introduced, invasive species, $R$. marina $(12.77 \%)$ was observed in all types of water systems, particularly in transects near human settlements and agricultural areas. It was found on the ground and leaf litter microhabitats. Platymantis dorsalis was the only species observed in the thick litterfall of the ground microhabitat (Type III). This cryptic species utilizes detritus of the forest floor (Alcala, Brown 1998), and thus prefers living on the ground (Calo, Nuñeza 2015). F. moodiei (4.26\%) and $F$. vittigera (5.67\%) utilized aquatic and terrestrial microhabitats of disturbed areas. These amphibian species

Table 2. Microhabitat preference, abundance and relative abundance (in brackets, \%) of anurans within the water systems of Andanan Watershed, Agusan del Sur during the sampling period. Microhabitat types: I, arboreal; II, aquatic; III, terrestrial

\begin{tabular}{|c|c|c|c|c|c|c|c|c|c|c|}
\hline \multirow[t]{2}{*}{ Species } & \multicolumn{3}{|c|}{ River } & \multicolumn{3}{|c|}{ Streams and creeks } & \multicolumn{3}{|c|}{ Lake } & \multirow[t]{2}{*}{ Total } \\
\hline & I & II & III & I & II & III & I & II & III & \\
\hline Rhinella marina & 0 & 0 & $\begin{array}{c}5 \\
(27.78)\end{array}$ & 0 & 0 & $\begin{array}{c}5 \\
(27.78)\end{array}$ & 0 & 0 & $\begin{array}{c}8 \\
(44.44)\end{array}$ & $\begin{array}{c}18 \\
(12.77)\end{array}$ \\
\hline Platymantis dorsalis & 0 & 0 & 0 & 0 & 0 & $1(100)$ & 0 & 0 & 0 & $1(0.71)$ \\
\hline Fejervarya moodiei & 0 & $\begin{array}{c}1 \\
(16.67)\end{array}$ & 0 & 0 & 0 & 0 & 0 & $\begin{array}{c}5 \\
(83.33)\end{array}$ & 0 & $6(4.26)$ \\
\hline Fejervarya vittigera & 0 & 0 & 0 & 0 & $1(12.5)$ & 0 & 0 & $5(62.5)$ & $2(25)$ & $8(5.67)$ \\
\hline Hoplobatrachus rugulosus & 0 & $1(100)$ & 0 & 0 & 0 & 0 & 0 & 0 & 0 & $1(0.71)$ \\
\hline Limnonectes magnus & 0 & $\begin{array}{c}11 \\
(22.92)\end{array}$ & $\begin{array}{c}7 \\
(14.58)\end{array}$ & 0 & $\begin{array}{c}7 \\
(14.58)\end{array}$ & $4(8.33)$ & 0 & $12(25)$ & 7 14.58) & $\begin{array}{c}48 \\
(34.04)\end{array}$ \\
\hline Megophrys stejnegeri & 0 & 0 & 0 & 0 & $\begin{array}{c}15 \\
(68.18)\end{array}$ & $\begin{array}{c}7 \\
(31.82)\end{array}$ & 0 & 0 & 0 & $\begin{array}{c}22 \\
(15.60)\end{array}$ \\
\hline Kalophrynus pleurostigma & 0 & 0 & 0 & 0 & 0 & 0 & 0 & 0 & $3(100)$ & $3(2.13)$ \\
\hline Kaloula conjuncta meridionalis & 0 & 0 & $2(100)$ & 0 & 0 & 0 & 0 & 0 & 0 & $2(1.42)$ \\
\hline Pulchrana grandocula & 0 & $9(50)$ & $\begin{array}{c}5 \\
(27.78)\end{array}$ & 0 & $\begin{array}{c}2 \\
(11.11)\end{array}$ & $1(5.55)$ & 0 & $1(5.55)$ & 0 & $\begin{array}{c}18 \\
(12.77)\end{array}$ \\
\hline Polypedates leucomystax & $1(7.14)$ & 0 & 0 & $\begin{array}{c}2 \\
(14.29)\end{array}$ & 0 & 0 & $\begin{array}{c}8 \\
(57.14)\end{array}$ & 0 & $3(21.43$ & $\begin{array}{c}14 \\
(9.93)\end{array}$ \\
\hline
\end{tabular}



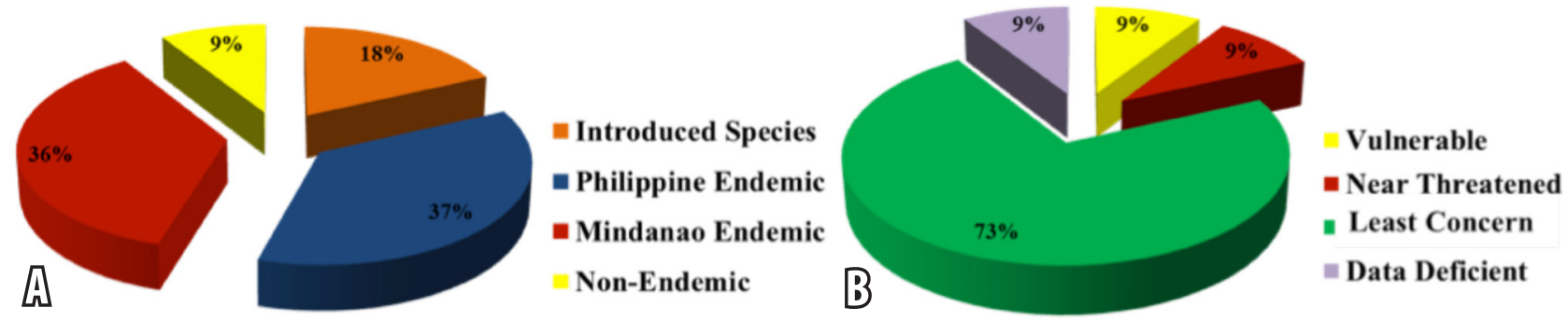

Fig. 3. The distribution status (A) and IUCN conservation status (B) of the recorded anurans during the sampling period.

were commonly encountered in all forms of standing water (Alcala 1986) in the lowland agricultural areas (Brown et al. 2013). The only species found in the flooded area adjacent to the river was $H$. rugulosus $(0.71 \%)$. L. magnus, a near threatened species, was seen in all sites and encountered in type II and type III microhabitats and was the most abundant species recorded (34.04\%). Three individuals of $K$. pleurostigma were consistently encountered on the ground and on detritus of the forest floor. M. stejnegeri (15.60\%) and P. grandocula (12.77\%) were frequently encountered on rocks of swiftly moving water in lowlands and at montane elevation, in forest rivers, streams, and ponds (Alcala et al. 2012). The Mindanao endemic, M. stejnegeri, was common. This species has a wide range of ecological tolerance (Sanguila et al. 2016). The species was also encountered in disturbed sampling sites of the Andanan Watershed Forest. Individuals of P. leucomystax (9.93\%) were encountered in both Type I and Type II microhabitats and found perching on banana leaves and dead corn husks in cultivated areas.

\section{Biodiversity indices and similarity measures across stations} Species composition differed between types of water systems (Table 3). Among the 11 anurans species recorded in the study, seven were encountered in the river and lake. Lake Danao harbored the highest number of individuals $(n$ $=54)$. Species diversity was highest in Lake Danao $\left(H^{\prime}=\right.$ 1.69), followed by the Calaitan river $\left(H^{\prime}=1.40\right)$ and lastly, in streams and creeks $\left(H^{\prime}=1.30\right)$. Populations of anurans were evenly distributed with no species dominating the area.

According to Water Notes (2000), riparian zones with high plant diversity and productivity provide diverse and abundant habitat to animals. The high species diversity recorded in the area was due to minimal disturbance. The area was declared protected under Proclamation No. 734, S. 1991 (PENRO Agusan del Sur 2016). However, several patches of forest areas had been converted to cultivated areas, like falcata plantation and several plantations of crop plants, which threaten the habitat of these anurans.

The lake had the higher number of individuals and species, but this does not imply that only the lake should be protected, since all types of the studied water systems supported different species of anurans. Amphibians require specific and unaltered habitat types for survival (Graeter 2005), and thus no one habitat is suitable for all amphibian species.

There were no anurans captured (although there were calls heard) in transects 1 and 2 (the first two transects in the stream) probably because the transects were located adjacent to cultivated areas and beside a very steep terrain that hindered the collection effort (Fig. 4A). H. rugulosus and $P$. dorsalis were encountered in only one transect. $L$. magnus was recorded in almost all of the transects surveyed (14 out of 18 transects).

The species composition and the number of individuals varied among the different water systems (Fig. 4B). The cluster analysis showed two groups, one included the stream and the other grouped together the lake and river. Similarity between these was 0.44 . Most of the species observed in the lake were also found in the river (P. grandocula, L. magnus, R. marina, P. leucomystax, F. moodiei, and F. vittigera), which explains why these habitats clustered together. Two amphibian species (M. stejnegeri and P. dorsalis) caused the difference between communities of the streams and other water systems.

ANOVA indicated no significant difference between

Table 3. Anuran diversity indices of the sampling sites within the water systems of Calaitan, Andanan Watershed, Agusan del Sur during the sampling period

\begin{tabular}{lcccc} 
Biodiversity indices & \multicolumn{2}{c}{ Sampling sites } & \multicolumn{1}{c}{ Total } \\
\cline { 2 - 3 } & Calaitan river & Streams and creeks & Lake Danao & 11 \\
Species richness (S) & 7 & 6 & 7 & 141 \\
Abundance & 42 & 43 & 54 & 1.69 \\
Species diversity (H') & 1.40 & 1.30 & 0.78 & 0.62 \\
Species evenness (E) & 0.58 & 0.61 & 0.22 & 0.19 \\
Species dominance (D) & 0.31 & 0.35 &
\end{tabular}


A

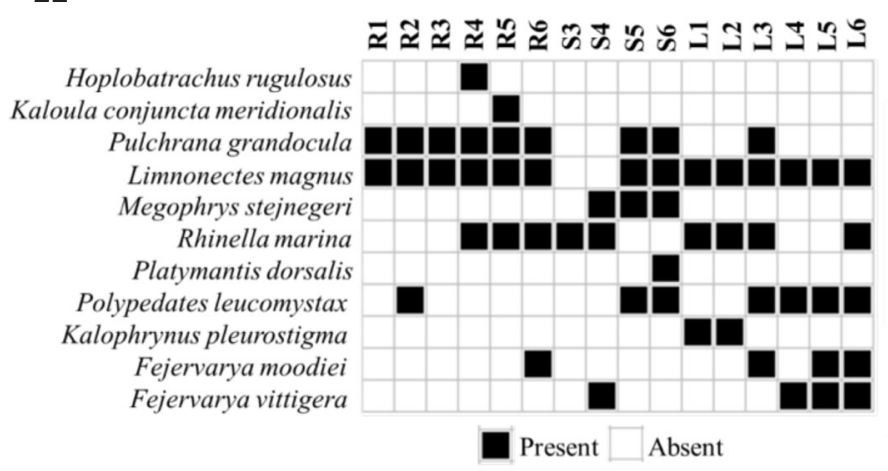

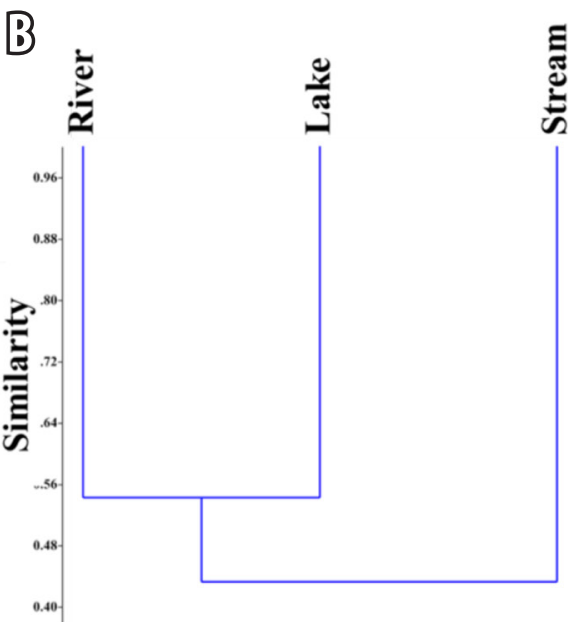

Fig. 4. Seriation analysis of anurans in 18 transects established within the study area (A) and cluster analysis using Bray-Curtis similarity matrix between the three water systems of Andanan Watershed, Agusan del Sur (B). R, river; S, stream; L, lake.

water systems $(F=0.0874, P=0.9167)$; the number of individuals and species richness were similar between water systems. However, the habitats significantly differed in species composition $(F=2.461, P=0.0376)$. Indicating the extreme abundance of $L$. magnus was very abundant in all sites. $P$. dorsalis, $H$. rugulosus, $K$. pleurostigma and $K$. conjuncta meridionalis had the lowest number of individuals.

\section{Species accounts}

The species accounts provide descriptions of the anurans recorded in the study area. Images of the collected species are given in Fig. 5.

\section{Rhinella marina (Linnaeus, 1758); Bufonidae}

Rhinella marina (cane toad) is an introduced species common in residential and agricultural areas throughout the Philippines (Brown et al. 2012). It is regarded as a least-concern species of the IUCN (2016). The species was observed in terrestrial microhabitat of disturbed areas. Average morphometrics of the individuals encountered were as follows: $\mathrm{SVL}=124.67 \mathrm{~mm}, \mathrm{HL}=26.3 \mathrm{~mm}, \mathrm{HW}=$ $33 \mathrm{~mm}, \mathrm{FL}=54 \mathrm{~mm}, \mathrm{LL}=47 \mathrm{~mm}$ and $\mathrm{TW}=25 \mathrm{~g}$. Snout to vent length ranged between 100 to $150 \mathrm{~mm}$.

Platymantis dorsalis (Dumeril, 1853); Ceratobatrachidae Platymantis dorsalis (Common Forest Frog) utilized terrestrial microhabitats. It is s Philippine endemic and a least concern species. Only one individual was observed on thick litterfall of the forest floor in the stream area. $P$. dorsalis is distributed throughout the Philippines. This species inhabits both undisturbed and disturbed lower montane and lowland forest habitats (IUCN 2016).

\section{Fejervarya moodiei (Taylor, 1920); Dicroglossidae}

Fejervarya moodiei is a Philippine endemic and is regarded as "Data Deficient" by the IUCN (2016). The slight dermal flap on tarsus is a distinguishing character between $F$. moodiei and F. vittigera. The average morphometrics were: $\mathrm{SVL}=63 \mathrm{~mm}, \mathrm{HL}=16 \mathrm{~mm}, \mathrm{HW}=19.5 \mathrm{~mm}, \mathrm{FL}=13 \mathrm{~mm}$, $\mathrm{LL}=31 \mathrm{~mm}$ and $\mathrm{TW}=10 \mathrm{~g}$. Snout to vent length ranged between 48 to $70 \mathrm{~mm}$.

\section{Fejervarya vittigera (Wiegmann, 1834); Dicroglossidae}

Fejervarya vittigera, commonly known as the common pond frog, was numerously observed around the riparian zone of Lake Danao. F. vittigera is a Philippine endemic and a least concern species. Stagnant water, pools and muddy substrate also served as microhabitats of these species. Specimens were also collected by Devan-Song and Brown (2012) in puddles along the muddy road in the Subic Bay Area and low and highly disturbed areas with standing water (Brown et al. 2013). Average morphometrics were as follows: $\mathrm{SVL}=63.67 \mathrm{~mm}, \mathrm{HL}=16.67 \mathrm{~mm}, \mathrm{HW}=19.5 \mathrm{~mm}$, $\mathrm{FL}=13.67 \mathrm{~mm}, \mathrm{LL}=32.67 \mathrm{~mm}$ and $\mathrm{TW}=10 \mathrm{~g}$. Snout to vent length ranged between 48 to $70 \mathrm{~mm}$.

\section{Hoplobatrachus rugulosus (Wiegmann, 1834); \\ Dicroglossidae}

Hoplobatrachus rugulosus (East Asian bullfrog, Chinese edible frog) is one of the five invasive alien species found in the Philippines (Diesmos et al. 2006), along with R. marina. It is a least concern species (IUCN 2016). H. rugulosus was introduced in the Philippines for commercial farming. This species was highly invasive through repeated episodes of anthropogenic introductions (Diesmos et al.2006). Average morphometrics were: $\mathrm{SVL}=101 \mathrm{~mm}, \mathrm{HL}=24 \mathrm{~mm}, \mathrm{HW}=$ $26 \mathrm{~mm}, \mathrm{FL}=32 \mathrm{~mm}, \mathrm{LL}=37 \mathrm{~mm}$ and $\mathrm{TW}=15 \mathrm{~g}$.

\section{Limnonectes magnus (Stejneger, 1910); Dicroglossidae} A high abundance of Limnonectes magnus (giant Philippine frog) was encountered in the area. This near-threatened, socio-economically important, and Mindanao faunal endemic amphibian was encountered in aquatic and 

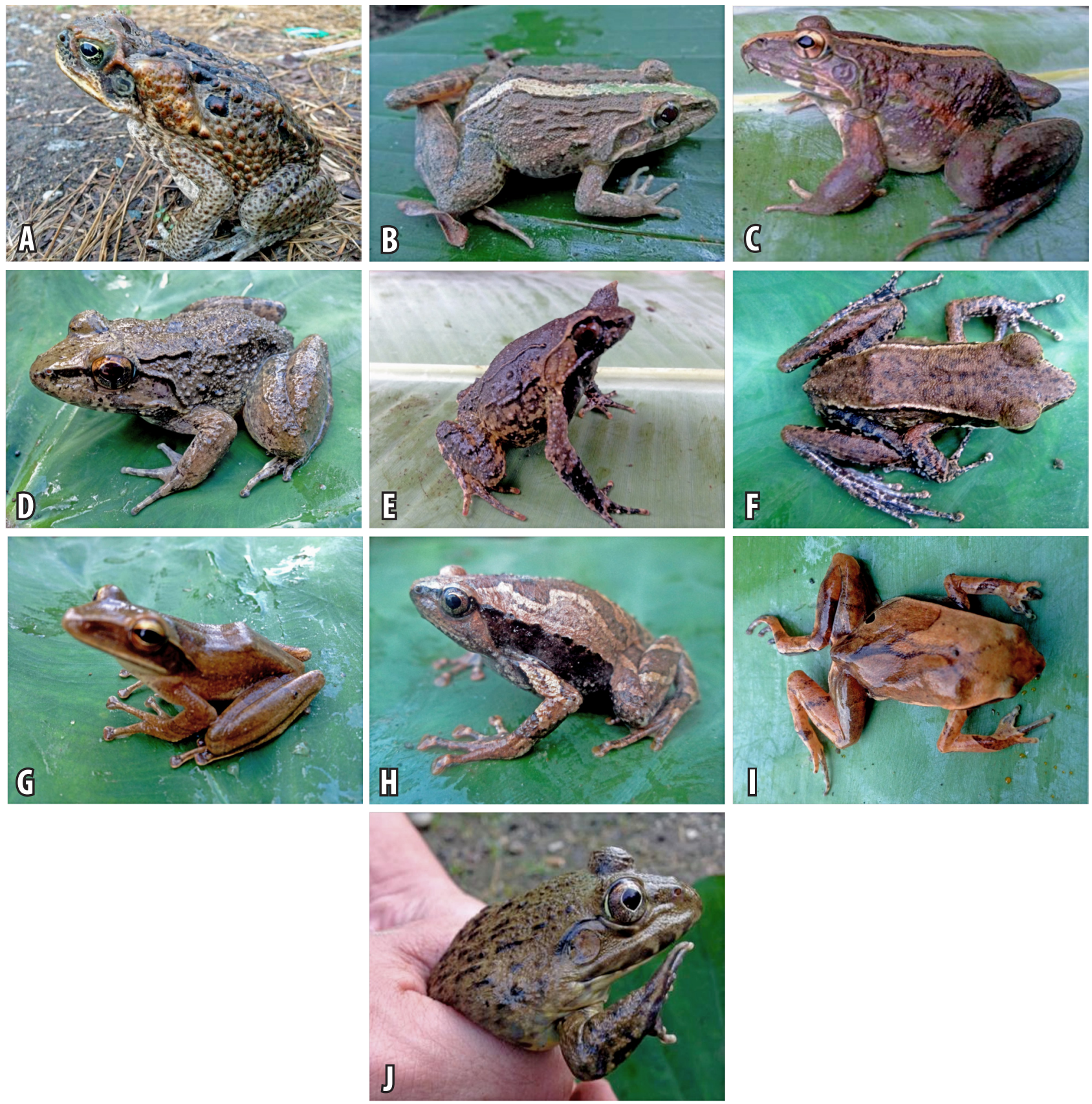

Fig. 5. Some species of anurans within the water systems of Andanan Watershed, Agusan del Sur, Philippines. A, Rhinella marina; B, Fejervarya moodiei; C, Fejervarya vittigera; D, Limnonectes magnus; E, Megophrys stejnegeri; F, Pulchrana grandocula; G, Polypedates leucomystax; H, Kaloula conjuncta meridionalis; I, Kalophrynus pleurostigma; J, Hoplobatrachus rugulosus. Photos by C.L. Solania.

terrestrial microhabitat. Overharvesting of this species for food consumption was perceived as a threat to the population of this species. Average morphometrics were: $\mathrm{SVL}=65.03 \mathrm{~mm}, \mathrm{HL}=17.87 \mathrm{~mm}, \mathrm{HW}=21.57 \mathrm{~mm}, \mathrm{FL}=$ $19.03 \mathrm{~mm}, \mathrm{LL}=32.77 \mathrm{~mm}$ and $\mathrm{TW}=11.17 \mathrm{~g}$. Snout to vent length ranged between 45 to $91 \mathrm{~mm}$.

\section{Megophrys stejnegeri (Taylor, 1920); Megophryidae}

Megophrys stejnegeri (Mindanao horned frog, Southeast Asian horned toad) was abundantly observed in the stream area of Barangay Calaitan, Andanan Watershed, Bayugan, Agusan del Sur within the elevation range of 116 to 183 masl. This species is dependent on mountain streams where it bread and reproduced (IUCN 2016). M. stejnegeri is a Mindanao faunal endemic and has a "vulnerable" conservation status. Average morphometrics were: SVL = $52.75 \mathrm{~mm}, \mathrm{HL}=16.8 \mathrm{~mm}, \mathrm{HW}=18.13 \mathrm{~mm}, \mathrm{FL}=14 \mathrm{~mm}$, $\mathrm{LL}=20.38 \mathrm{~mm}$ and TW $=14.13 \mathrm{~g}$. Snout to vent length ranged between 48 to $57 \mathrm{~mm}$. 


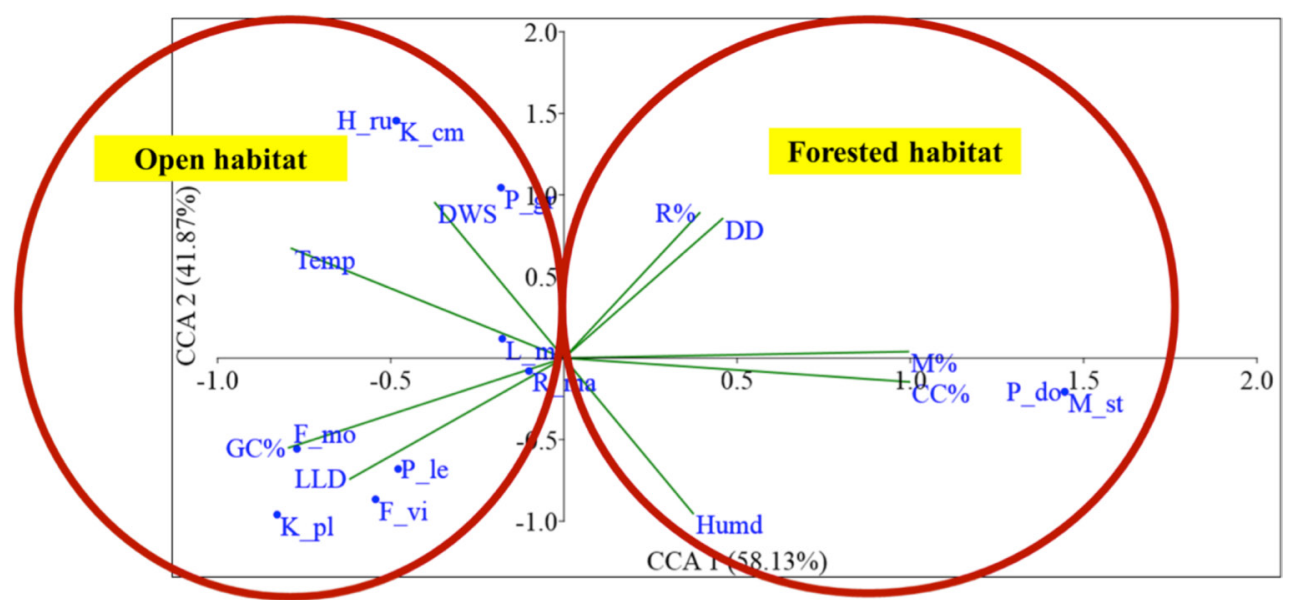

Fig. 6. Canonical correspondence analysis (CCA) showing the relationship between environmental variables and anuran richness and abundance. R_ma, Rhinella marina; F_mo, Fejervarya moodiei; F_vi, Fejervarya vittigera; L_ma, Limnonectes magnus; M_st, Megophrys stejnegeri; P_gr, Pulchrana grandocula; P_le, Polypedates leucomystax; K_cm, Kaloula conjuncta meridionalis; K_pl, Kalophrynus pleurostigma; H_ru, Hoplobatrachus rugulosus; P_do, Platymantis dorsalis.

Kalophrynus pleurostigma (Tschudi, 1838); Microhylidae Kalophrynus pleurostigma (black-spotted sticky frog) was only observed in Lake Danao, sitting on leaf litter near rotting logs of the forest floor. A Mindanao faunal endemic and a least concern species of the IUCN (2016). Average morphometrics were as follows: $\mathrm{SVL}=40 \mathrm{~mm}, \mathrm{HL}=8 \mathrm{~mm}$, $\mathrm{HW}=12 \mathrm{~mm}, \mathrm{FL}=12 \mathrm{~mm}, \mathrm{LL}=16 \mathrm{~mm}$ and $\mathrm{TW}=4 \mathrm{~g}$.

\section{Kaloula conjuncta meridionalis (Peters, 1863); Microhylidae}

Kaloula conjuncta meridionalis (Philippine narrowmouth toad) was only observed in the Calaitan River area, and it utilized terrestrial microhabitats. It is a Philippine endemic and a least concern species (IUCN 2016). Taylor (1920) described two subspecies of Kaloula conjuncta: Kaloula conjuncta stickeli of Leyte and Kaloula conjuncta meridionalis of the Mindanao Island. Average morphometrics were: SVL $=41 \mathrm{~mm}, \mathrm{HL}=10 \mathrm{~mm}, \mathrm{HW}=11 \mathrm{~mm}, \mathrm{FL}=12 \mathrm{~mm}, \mathrm{LL}=$ $10 \mathrm{~mm}$ and $\mathrm{TW}=4 \mathrm{~g}$.

\section{Pulchrana grandocula (Taylor, 1920); Ranidae}

Pulchrana grandocula (big-eyed frog) utilized terrestrial and aquatic microhabitats. It is a Mindanao faunal endemic and a least concern species (IUCN 2016). This species was encountered in all water systems surveyed with average morphometrics of SVL $=48.88 \mathrm{~mm}, \mathrm{HL}=15.38 \mathrm{~mm}, \mathrm{HW}$ $=17.13 \mathrm{~mm}, \mathrm{FL}=17.63 \mathrm{~mm}, \mathrm{LL}=23.63 \mathrm{~mm}$ and $\mathrm{TW}=$ $4.13 \mathrm{~g}$. Snout to vent length ranged between 40 to $68 \mathrm{~mm}$.

\section{Polypedates leucomystax (Gravenhorst, 1829); Rhacophoridae}

Polypedates leucomystax (common tree frog) was observed perching on leaves of banana, and dead corn husks. It was most abundant in the Lake Danao area (characterized by cultivated and secondary growth forest). P. leucomystax is a non-endemic and a least concern species (IUCN 2016). It was encountered in arboreal and terrestrial microhabitats. The conversion of forested areas to monoculture agriculture may have facilitated expansion of its range and biological diversification (Brown et al. 2010). Average morphometrics were as follows: $\mathrm{SVL}=57 \mathrm{~mm}, \mathrm{HL}=17.8 \mathrm{~mm}, \mathrm{HW}=18.2$ $\mathrm{mm}, \mathrm{FL}=13.4 \mathrm{~mm}, \mathrm{LL}=28.8 \mathrm{~mm}$ and $\mathrm{TW}=5 \mathrm{~g}$. Snout to vent length ranged between 50 to $68 \mathrm{~mm}$.

\section{Anuran-habitat association}

Anurans species are habitat specific. Species of herpetofauna associated with mature forest are more common than those associated with secondary succession forest (Greenberg 2001). However, some frogs and toads may increase in number even after disturbance, since they can tolerate environmental changes (Moorman et al. 2011). Most anurans require water for egg deposition and in the early stages of their lifecycle (Duellman, Trueb 1986). Therefore, the presence of water bodies is essential as natural habitats of anurans.

The ordination biplot (Fig. 6) showed the relationship of anurans to the environmental variables tested. The significant environmental variables, shown as vectors (lines), are associated with the faunal gradients (Hammer 2011). The left side of the biplot can be classified as an open habitat (cultivated area), withhigher values of leaf litter depth, percentage ground cover, temperature and distance to the water system. Species associated with these ecological variables were $H$. rugulosus, $K$. conjuncta meridionalis, $F$. moodiei, P. leucomystax, F. vittigera, and K. pleurostigma. Secondary forest habitat on the right side of the ordination was associated with environmental variables such as higher humidity, canopy cover, moss percentage, rock percentage, and distance to disturbance. Changes in these variables can affect the abundance of the vulnerable $M$. stejnegeri and the cryptic P. dorsalis. L. magnus and R. marina can be considered as generalist species, because of their 
proximity to the center of the biplot. $R$. marina is known to inhabit disturbed areas (Alcala 1986) and fluctuation in the environmental variables cannot affect its distribution. Presence of non-native species can increase competition pressure to the native frogs regarding food and habitat. L. magnus was encountered in all sampling stations in all water systems. Although this species is near-threatened and a Mindanao faunal endemic, there is no literature supporting the actual decline of L. magnus (Plaza, Sanguila 2015). The high abundance of this species in the area (as encountered) suggests its relative dominance compared to the abundance of other species.

Habitat association suggests the importance of the forest as a refuge since anurans are ectothermic organisms (cannot regulate their body temperature), making them very dependent on the environment. More native anuran species occur inundisturbed habitats.

\section{Conclusions and recommendations}

The water systems of the Andanan Watershed Forest Reserve in Barangay Calaitan harbor 11 species of anurans from seven families. The Philippine-endemics comprise most of the population (73\% of species), followed by introduced species (18\%) and non-endemics (9\%). M. stejnegeri, a Mindanao faunal endemic was only recorded by streams at higher elevations while the socioeconomically and near-threatened L. magnus was recorded in all types of water systems and across all elevations. Lake Danao had the highest diversity $\left(H^{\prime}=1.69\right)$ and largest number of recorded anurans $(n=54)$. Most of the anurans utilized both terrestrial and aquatic microhabitats. Most of the Philippine endemic anurans were forest-dependent. The conversion of remaining forest to cultivated areas for falcata is a significant threat to Philippine endemic species and most especially to Mindanao faunal endemics. Protection of the remaining forest blocks in Andanan Watershed to avoid declines of forest-dependent anurans has high conservation priority.

\section{Acknowledgements}

We would like to thank Dr. Rafe M. Brown for the verification of the anurans recorded in the area, also the Department of Biology Laboratory of Caraga State University for providing the materials used in the study and Mr. Niel Jun B. Naling for the technical assistance and map layouts. We would also like to thank Mr. Jerry T. Cuadrado for helping in the field. We also thank the Local Government Unit of Bayugan and Barangay Calaitan for the field assistance and safety measures during the fieldworks.

\section{References}

Alcala A.C., Brown W.C. 1986. Guide to Philippine Flora and Fauna. Vol. X. Amphibians and Reptiles. Natural Resources Management Center, Ministry of Environment and Natural Resources and University of the Philippines, Manila.
Alcala A.C., Brown W.C. 1998. Philippine Amphibians: an Illustrated Field Guide. Bookmark Inc. Press, Makati.

Alcala A.C., Bucol A.A., Diesmos A.C., Brown R.M. 2012. Vulnerability of Philippine amphibians to climate change. Philippine J. Sci. 141: 77-87.

Alterr S., Goyenechea A., Schubert D.J. 2011. The international trade in frogs' legs and its ecological impact. Pro Wildlife. Defenders of Wildlife. Animal Welfare Institute.

Blaustein A.R., Wake D.B. 1995. The puzzle of declining amphibian populations. Sci. Amer. 272: 52-57.

Brown R.M., Oliveros C.H., Siler C.D., Fernandez J.B., Welton L.J., Buenavente P.A.C., Diesmos M.L.L., Diesmos A.C. 2012. Amphibians and reptiles of Luzon Island (Philippines), VII: Herpetofauna of Ilocos Norte Province, Northern Cordillera Mountain Range. Checklist 8: 469-490.

Brown R.M., Siler C.D., Oliveros C.A., Esselstyn J.A., Diesmos A.C., Hosner P.A., Linkem C.W., Barley A.J., Oaks J.R., Sanguila M.B., Welton L.J., Blackburn D., Moyle R.G., Peterson A.T., Alcala A.C. 2013. Evolutionary processes of diversification in a ,odel island archipelago. Annu. Rev. Ecol. Evol. Syst. 44: $24.1-24.5$

Brown R.M., Linkem C.W., Siler C.D., Sukumaran J., Esselstyn J.A., Diesmos A.C., Iskandar D.T., Bickford D., Evans B.J., McGuire J.A., Grismer L., Supritna J., Andayani N. 2010. Phylogeography and historical demography of Polypedates lecomystax in the islands of Indonesia and the Philippines: Evidence for recent human-mediated range expansion? Mol. Phylogen. Evol. 57: 598-619.

Brown R.M., Diesmos A.C. 2009. Philippines, biology. In: Gillespie R., Clague D. (eds) Encyclopedia of Islands. University of California Press, Berkeley, pp. 723-732.

Calo T.J.V., Nuñeza OM.. 2015. Species richness and endemism of anurans in Bega Watershed, Prosperidad, Agusan del Sur, Philippines. J. Biodiv. Environ. Sci. 7: 1-14.

Collins J.P., Storfer A. 2003. Global amphibian declines: sorting the hypotheses. Divers. Distrib. 9: 89-98.

Devan-Song A., Brown R.M. 2012. Amphibians and reptiles of Luzon Island, Philippines, VI: the Herpetofauna of the Subic Bay Area. Asian Herpetol. Res. 3: 1-20.

Diesmos A.C., Brown R.M. 2011. Diversity, biogeography and conservation of Philippine amphibians. In: Proceedings of the Conference "Biology of the Amphibians in the Sunda Region, South-east Asia." Biology and Conservation of Tropical Asian Amphibians. Universiti Malaysia Sarawak, Kota Samarahan, Sarawak, Malaysia, pp 26-49.

Diesmos A.C., Diesmos M.L., Brown R.M. 2006. Status and distribution of alien frogs in the Philippines. J. Environ. Sci. Manage. 9: 41-53.

Diesmos A.C., Watters J.L., Huron N.A., Davis D.R., Alcala A.C., Crombie R.I., Afuang L.E., Gee-Das G., Sison R.V., Sanguila MB., Penrod M.L., Labonte M.J., Davey C.S., Leone E.A., Diesmos M.L., Sy E.Y., Welton L.J., Brown R.M., Siler C.D. 2015. Amphibians of the Philippines, Part I: Checklist of the species. Proc. Calif. Acad. Sci. 62: 457-539.

Duellman W.E., Trueb L. 1986. Biology of Amphibians. McGrawHill, New York.

Ernst R., Linsenmair K.E., Rodel M.O. 2006. Diversity erosion beyond the species level: Dramatic loss of functional diversity after selective logging in two tropical amphibian communities. Biol. Conserv. 133: 143-155.

Fernando E.S. 1998. Forest formations and flora of the Philippines. Handout in FBS 21. College of Forestry and Natural Resources, 
University of the Philippines at Los Baños (Unpublished).

Greenberg C.H. 2001. Response of reptile and amphibian communities to canopy gaps created by wind disturbance in the southern Appalachians. Forest Ecol. Manage. 148: 135-144.

Hammer O. 2011. Ecological Ordination with Past. Natural History Museum, University of Oslo.

Heaney L.R. 1985. Zoogeographic evidence for middle and late Pleistocene land bridges to the Philippines. Mod. Quat. Res. 9: $127-143$.

Jacosalem L.J.P.2005. Endemic Amphibians and their microhabitats in Mt. Magdiwata, San Francisco, Agusan del Sur. BS Biology (Zoology). MSU IIT. /Unpublished manuscript/

Kiesecker J.M., Blaustein A.R., Belden L.K. 2001. Complex causes of amphibian populations declines. Nature 410: 681-684.

Krisnawati H., Varis E., Kallio M., Kanninen M. 2011. Paraserianthes falcataria (L.) Nielsen: ecology, silviculture, and productivity. CIFOR, Bogor, Indonesia.

Marsh D.M., Pearman P.B. 1997. Effects of habitat fragmentation on the abundance of two species of Leptodactylid frogs in the Andean montane forest. Conserv. Biol. 11: 1323-1328.

Moorman C.E., Russell K.R., Greenberg C.H. 2011. Reptile and amphibian response to hardwood forest management and early successional habitats. In: Greenberg C., Collins B., Thompson III F. (eds) Sustaining Young Forest Communities. Managing Forest Ecosystems, Vol 21. Springer, Dordrecht.

PENRO Agusan del Sur. 2016. Environmental and Natural Resources Statistics. Retrieved from: hhtps:www. denrpenroads. com.

Petranka J.W., Murray S.S. 2001. Effectiveness of removal sampling for determining salamander density and biomass: a case study in an Appalachian streamside community. J. Herpetol. 35: 36-44.

Plaza J.L., Sanguila M.B.2015. Preliminary report on the anurans of
Mount Hilong-hilong, Agusan Del Norte, Eastern Mindanao, Philippines. Asian Herpetol. Res. 6: 18-33.

Prieto I.R., Juricic E.F. 2005. Effects of direct disturbance on the endemic Iberian frog Rana iberica at individual and population levels. Biol. Conserv. 123: 1-9.

Sanguila M.B, Cobb K.A, Siler C.D, Diesmos A.C, Alcala A.C, Brown R.M. 2016. The amphibians and reptiles of Mindanao Island, southern Philippines, II: the herpetofauna of northeast Mindanao and adjacent islands. ZooKeys 624: 1-132.

Semlitsch R.D., Conner C.A., Hocking D.J., Rittenhouse T.A.J., Harper E.B. 2008. Effects of timber harvesting on pondbreeding amphibian persistence: Testing the evacuation hypothesis. Ecol. Applic. 18: 283-289.

Supsup C.E., Puna N.M., Asis A.A., Redoblado B.R., Panaguinit M.F.G., Guinto F.M., Rico E.B, Diesmos A.C., Brown R.M, Mallari N.A.D. 2016. Amphibians and reptiles of Cebu, Philippines: the poorly understood herpetofauna of an islands with very little remaining natural habitat. Asian Herpetol. Res. 7: 151-179.

Taylor E.H. 1920. Philippine Amphibia. Philip. J. Sci. 16: 213-359.

Water Fact Sheet. 2010. Difference in Water Quality Impairments: Lakes vs. Rivers. Iowa Department of Natural Resources, Geological, and Water Survey. 109 Trowbridge Hall, Iowa City, IA 52242-1319.

Water Notes. 2000. Advisory Notes for Land Managers on River and Wetland Restoration.

Whiles M.R., Lips K.R., Pringle C.M., Kilham S.S., Bixby R.J., Brenes R., Connelly S., Colon Gaud J.C., Hunte-Brown M., Huryn A.D., Montgomery C., Peterson S. 2006. The effects of amphibians population declines on the structure and function of Neotropical stream ecosystems. Front. Ecol. Environ. 4: 2734 . 